Article

\title{
The Importance of Lactose in the Human Diet: Outcomes of a Mexican Consensus Meeting
}

\author{
Enrique Romero-Velarde ${ }^{1, *}$, Dagoberto Delgado-Franco ${ }^{2}$, Mariana García-Gutiérrez ${ }^{3}$, \\ Carmen Gurrola-Díaz ${ }^{4}$, Alfredo Larrosa-Haro ${ }^{5}$, Ericka Montijo-Barrios ${ }^{6}$, Frits A. J. Muskiet ${ }^{7}$, \\ Belinda Vargas-Guerrero ${ }^{4}$ and Jan Geurts ${ }^{8}$
}

1 Instituto de Nutrición Humana, Universidad de Guadalajara and Hospital Civil de Guadalajara “Dr. Juan I. Menchaca", 44340 Guadalajara, Jalisco, Mexico

2 Neonatology Department. ABC Medical Center, 01120 Mexico City and Instituto Tecnológico de Estudios Superiores de Monterrey, 64849 Monterrey, Mexico; ddelgadof@abchospital.com

3 Endocrinology Department, Hospital Ángeles del Carmen. 44670 Guadalajara, Jalisco, Mexico; mariana.endoc@gmail.com

4 Departamento de Biología Molecular y Genómica. Centro Universitario de Ciencias de la Salud, Universidad de Guadalajara, 44340 Guadalajara, Jalisco, Mexico; carmenhpv@yahoo.de (C.G.-D.); bevargro@hotmail.com (B.V.-G.)

5 Instituto de Nutrición Humana, Universidad de Guadalajara, 44340 Guadalajara, Jalisco, Mexico; alfredo.larrosa@academcos.udg.mx

6 Servicio de Gastroenterología. Instituto Nacional de Pediatría, 04530 Mexico City, Mexico; erickamontijo@yahoo.com

7 Laboratory Medicine, University Medical Center Groningen and University of Groningen, 9713 GZ Groningen, The Netherlands; f.a.j.muskiet@umcg.nl

8 FrieslandCampina, 3818 LEAmersfoort, The Netherlands; jan.geurts@frieslandcampina.com

* Correspondence: enrique.romerovelarde@gmail.com; Tel.: +52-33-3618-9667

Received: 4 October 2019; Accepted: 8 November 2019; Published: 12 November 2019

check for updates

\begin{abstract}
Lactose is a unique component of breast milk, many infant formulas and dairy products, and is widely used in pharmaceutical products. In spite of that, its role in human nutrition or lactose intolerance is generally not well-understood. For that reason, a 2-day-long lactose consensus meeting with health care professionals was organized in Mexico to come to a set of statements for which consensus could be gathered. Topics ranging from lactase expression to potential health benefits of lactose were introduced by experts, and that was followed by a discussion on concept statements. Interestingly, lactose does not seem to induce a neurological reward response when consumed. Although lactose digestion is optimal, it supplies galactose for liver glycogen synthesis. In infants, it cannot be ignored that lactose-derived galactose is needed for the synthesis of glycosylated macromolecules. At least beyond infancy, the low glycemic index of lactose might be metabolically beneficial. When lactase expression decreases, lactose maldigestion may lead to lactose intolerance symptoms. In infancy, the temporary replacing of lactose by other carbohydrates is only justified in case of severe intolerance symptoms. In those who show an (epi)genetic decrease or absence of lactase expression, a certain amount (for adults mostly up to $12 \mathrm{~g}$ per portion) of lactose can still be consumed. In these cases, lactose shows beneficial intestinal-microbiota-shaping effects. Avoiding lactose-containing products may imply a lower intake of other important nutrients, such as calcium and vitamin $B_{12}$ from dairy products, as well as an increased intake of less beneficial carbohydrates.
\end{abstract}

Keywords: lactose; lactose replacers; lactose intolerance; lactose maldigestion; lactase; galactose; microbiota; infants; children; adults 


\section{Introduction}

Lactose, as a unique carbohydrate in most mammalian milks, has been part of the human diet since our very origin. Nowadays, because of its chemical characteristics, lactose is found in many milk-derived products and is an important raw material in pharmaceutical products [1,2]. There are still questions, however, about the role of lactose (and thus dairy) in (1) infants and young children with symptoms of lactose intolerance, and (2) children and adults who are lactase non-persistent (LNP). LNP individuals hardly digest lactose and may show or develop symptoms of lactose intolerance [3-5].

Although dairy was introduced relatively late in the human diet, it appeared to be beneficial to its consumers, which resulted in initial mutations, leading to the ability to hydrolyze lactose lifelong (lactase persistence; LP). This created the opportunity to consume milk in relevant portions, thereby providing proteins of high biological value, and vitamins and minerals such as calcium [6,7]. Moreover, lactose in milk has a low glycemic index, which is generally considered a metabolic advantage. Recently, other benefits of lactose consumption via milk have been identified or suggested: shaping of the intestinal microbiota [8,9], exerting no neurologically rewarding effects when ingested [10,11], supporting immune function [12], and facilitating mineral absorption [13].

In recent years, the use of lactose-reduced or lactose-free infant formulae is, however, increasing in various countries, including Mexico. This is even the case for healthy infants and young children, who fully express the lactase enzyme and can, therefore, properly digest lactose. One of the contributing factors to this phenomenon could be the misdiagnosis of childhood functional gastrointestinal disorders (FGIDs) where complaints are incorrectly attributed to poor digestion of lactose. This, combined with the level of distress that the parents perceive in these situations, might explain, at least partly, why the transition to lactose-free or lactose-reduced formulae is so easily made [14,15]. Fear for "adverse" effects of milk/lactose consumption in early life may impact later stages of childhood and adolescence by reduction or elimination of milk from the diet, a habit that may lead to insufficient consumption of important nutrients needed for growth.

The purpose of the consensus meeting was to discuss and formulate a number of statements about lactose that represent the latest scientific insights and correct existing myths. This paper describes the discussions and provides the background on which the final statements were based.

\section{Methods}

To reach consensus on the nutritional and clinical importance of lactose, a total of 22 leading Mexican experts (representing the fields of pediatrics, gastroenterology, neonatology, clinical chemistry, genetics, endocrinology, and nutrition) from across the country, together with 2 experts from the Netherlands, convened in a 2-day meeting in Tequisquiapan, Querétaro, Mexico. Before the meeting and based on common questions about lactose, a set of statements was prepared. Next to that, 8 participants (topic leaders), considered to be experts in the field, were asked to prepare $30 \mathrm{~min}$ presentations on one of the statements. Presentations were given during the 2-day-meeting and each of the statements was extensively discussed within the group and amended where necessary. Consensus was achieved by incorporating all comments from participants into a written summary of the discussion for each topic. The summary documents were transformed into the present manuscript, including latest relevant publications, and were thoroughly reviewed by the topic leaders. The list of approved statements is presented in Section 3.14. Agreement on statements was given by each of the participants by email or oral communication.

\section{Results}

\subsection{Lactose}

The disaccharide lactose, with chemical structure galactose- $\beta 1$,4-glucose, has been evolutionary conserved in virtually all placental mammalian milks, albeit in varying concentrations depending on the species [1]. Compared to milk from other mammals, human milk is considered unique in its high 
sugar content; it contains about $70 \mathrm{~g} / \mathrm{L}$ lactose $(7 \%)$ contributing around $40 \%$ of the caloric value [10]. In solution, it exists in two basic configurations, $\alpha$ and $\beta$-lactose, which are continuously converted into each other through a process called mutarotation. They differ in the position of the hydroxyl group on the $\mathrm{C} 1$ atom of the glucose molecule, but both configurations display identical digestion and metabolism characteristics in vivo [16]. The specific $\beta-1,4$ glycosidic bond between galactose and glucose is relatively rare in nature (although also present in cellulose and chitin). It may protect the lactating breast or neonatal gastrointestinal tract (GI tract) against infection by selective limitation of environmental microorganisms that have more difficulties with fermenting lactose compared to simple, alpha-linked glucose polymers. As such, lactose may be important in the early shaping of the neonatal gut microbiota [1]. The importance of lactose in the process of lactation is evidenced by various evolutionary adaptations by mother and child. In the mammary gland, lactose is completely synthesized from glucose provided by the arterial blood supply, and has low solubility (only $10 \%$ that of sucrose at $25^{\circ} \mathrm{C}$ ) but high stability in solution, thereby preventing lactose from diffusing out of the Golgi and secretory vesicles [17]. As a consequence, lactose can be easily secreted and aid in drawing water into these organelles, as such, determining the volume of the milk produced. The stability of lactose in solution enables the body to transfer significant amounts of energy to the neonate without excessive osmotic effects [17].

Several physiological benefits have been attributed to lactose in breast milk. Besides serving as an energy source, lacking any rewarding effects, unlike other carbohydrates such as sucrose or maltodextrin $[10,11]$, it provides glucose and galactose, which serve as building blocks for various macromolecules (e.g., oligosaccharides, glycoproteins, and glycolipids) [18]. In addition, lactose is the least cariogenic amongst fermentable sugars [19], possesses a low glycemic index $(G I=46)[20]$ and can exert microbiota-modulating effects in the case of sufficient passage of undigested lactose into the lower intestine $[8,9]$. Furthermore, enzymatic hydrolysis into its monosaccharides is considered a re-hydration mechanism in the small intestine [21]. Lactose is widely used in food and pharmaceutical industries. Applications range from an energy source for lactic acid bacteria during dairy-product fermentation, in which its breakdown leads to the formation of specific flavor components, to its use as an excipient in oral, solid-dose pharmaceutical formulations [2].

\subsection{Lactase (LCT)}

Lactose needs to be broken down into its monosaccharides in order to be efficiently absorbed in the small intestine. Hydrolysis is controlled by lactase (LCT, also known as $\beta$-galactosidase or lactase phlorizin hydrolase (LPH)), a homodimeric enzyme anchored to the membranes of the small intestinal villus tips, with its highest expression being in the brush border of the mid-jejunum [22]. Maturation of the machinery for carbohydrate digestion and absorption occurs in a defined sequence during fetal development. Providing an adequate amount of nutrients is very important in order to reduce morbidity; however, the immature gastrointestinal system may represent a limitation. Therefore, understanding gastrointestinal development, which directly affects the metabolism of lactose, is key as it relates to the accretion of nutrients beneficial to the infant. Intestinal lactase activity is detectable in the fetal gut by eight weeks of gestation. Whereas sucrase, maltase, and isomaltase are usually almost fully active in preterm infants, lactase activity is low and proportional to gestational age (in infants $<34$ weeks, enzyme activity amounts to approximately $30 \%$ of that at term), but increases markedly from 24 to 40 weeks [23]. After the first feeding, there is a rapid increase in lactase activity to promote digestion of the lactose present in breast milk [24,25]; lactase-mediated hydrolysis of lactose typically exceeds $98 \%$ efficiency within five days of starting feeding [26]. Age, feeding, and nutrient composition have been shown to affect the development of intestinal lactase activity [27-29]. Premature babies that received early enteral feeding exhibited greater enzyme activity $(100 \%)$ than infants in the control group (60\%) [30]. Moreover, at 10 days old, lactase activity was higher in newborns that were fed with breast milk rather than formula [30]. Despite this relative "lactase deficiency" in the preterm infant, clinical symptoms of lactose intolerance are uncommon and the use of lactose is, 
therefore, not contraindicated [31]. Postnatal adaptive responses to carbohydrates ingested by the colonic microbiota further improve lactose digestion; even an excess of lactose that goes undigested by lactase in the brush border will be effectively fermented in the terminal ileum and colon by conversion into short-chain fatty acids [30]. During childhood and in a majority of children, lactase levels gradually decrease from a peak at birth to less than $10 \%$ of the preweaning level, with most of the change being observed at an age of about 2 years or older. However, lactase activity may persist into adulthood in some (sub)populations, which will be addressed in the next paragraph. Finally, congenital lactase deficiency has been described, but is rare; therefore, nutritional restriction of lactose is generally not necessary in term infants and children $[4,28]$.

\subsection{Development of Lactase Persistence (LP)}

Physiological down-regulation of lactase expression by $90 \%-95 \%$ occurs in the majority of humans $(\sim 65 \%)$ post-weaning in the absence of intestinal injury or disease, a wild-type condition known as lactase non-persistence (LNP) [3,32]. Lactase activity persists, however, in some populations, a condition known as lactase persistence (LP), which can be attributed to (differential) regulation of lactase biosynthesis. Historically, the practice of pastoralism with its associated increase in consumption of milk and milk-derived products triggered this development of LP. These are all relatively recent events which significantly impacted our culture, biology, genetics, and behavior. LP is the most strongly selected single-gene trait currently known that evolved in Europeans and some African and Asian groups over the last 10,000 years [33-37]. The estimated spread of LP in Europe is thought to have been a very fast process. In fact, it has been calculated that the percentage of the population surviving to reproductive age increased by $5 \%-10 \%$ each generation due to the development of this trait, indicating that LP must have provided strong health benefits [6,7]. To date, it is unclear when LP exactly developed; data suggests anywhere between 4000 and 7500 years ago, probably in Central Europe [6]. Early evidence of animal domestication in southwestern Asia extends back to around 12,000 years ago. While initially, domestic animals were exclusively exploited for their primary products in the early Neolithic era, the widespread use of their secondary products-particularly milk—followed immediately or very soon after [38-40]. Dairying seems to predate the development of LP by several millennia, which might be explained by the initial consumption of fermented milk products, as these contain reduced lactose levels, causing no intolerance symptoms. Thus, in the developing pastoral societies of Eurasia, LP may have evolved as an adaptation to the consumption of fresh dairy products, thereby improving daily nutrition. Considering the varied ecologies in which LP evolved, it is unlikely that one single hypothesis explains the strong signatures of natural selection inferred across multiple geographical regions.

\subsection{Regulation of Lactase Expression}

Lactase is composed of two monomers, each consisting of two catalytic sites: domain III (phlorizin-hydrolase; beta-glucosidase activity) and domain IV (lactase; beta-galactosidase activity) [41]. LCT is located on the long arm of chromosome 2, is composed of 17 exons [3], and is primarily regulated at the transcriptional level [32]. The current view is that after lactase activity has been fully established, it is not influenced by dietary changes and/or lactose intake any longer [32]. Rather, differential lactase expression (as previously indicated, highest in the mid-jejunum) is orchestrated by gut-region-specific expression of the many transcription factors [22]. On a molecular level, epigenetic silencing in the condition of LNP takes place in both an upstream enhancer, located in intron 13 of the "DNA replication licensing factor MCM6" gene [42], and the promoter region of LCT itself [43,44]. LP is caused by well described single nucleotide polymorphisms (SNPs) in the enhancer, and these genetic changes prevent the epigenetic silencing of lactase after weaning [42]. Interestingly, in some populations, substrates for the phlorizin hydrolase domain of LCT might have driven development and evolutionary selection of LP. In these LP populations, a variety of triggers for lactase biosynthesis might have provided individuals the capability to detoxify certain nutrients (e.g., phlorizin) or increase the bioavailability of 
beneficial substrates like flavonoids (e.g., quercetin) [45]. Although the prevailing view is that there are no lactase-inducing or silencing signals from the environment, accumulating evidence (epigenetics and in vitro studies [46-48]) suggest that this cannot be excluded.

\subsection{Lactose Maldigestion and Intolerance, and Lactose Replacements}

The non-immune mediated intolerance to carbohydrates is primarily due to maldigestion because of deficiency of enzymes or transporters, or is caused by overloading of intestinal brush border digestive/transport systems. Non-digested/-absorbed carbohydrates are readily fermented by the intestinal microbiota, resulting in the production of fermentation products, such as lactate, short-chain fatty acids (SCFAs), and several gasses $\left(\mathrm{CO}_{2}, \mathrm{H}_{2}\right.$, and $\left.\mathrm{CH}_{4}\right)$. Severe maldigestion of carbohydrates may cause osmotic diarrhea $[5,49,50]$.

Symptomatic lactose intolerance is the result of an impaired lactase capacity to properly digest lactose [3]. Congenital lactase deficiency, is an extremely rare, autosomal recessive condition caused by mutations in the lactase gene resulting in complete lactase absence [51,52]. Early in life, it is hypothesized (but unproven) that lactose maldigestion may, in rare cases, be caused by temporary lactase insufficiency (developmental or neonatal lactase deficiency) which generally resolves at three months of age, coinciding with the period of colicky behavior, although the role of lactose in infantile colic is controversial. Secondary lactase deficiency is a temporary decrease in lactase activity due to, for instance, damage of the intestinal villi of the small intestine. This may occur at any age, both in LNP and LP individuals. In the majority of people, and most often from late childhood onwards, lactose malabsorption has a genetic background (primary, adult-onset lactase deficiency) [4,5]. Lactose maldigestion and/or lactose malabsorption may result in clinical symptoms, such as distension of the small bowel, non-focal abdominal pain associated with bloating and flatulence, nausea, increased gut motility, and diarrhea. Additional systemic symptoms, such a headache, vertigo, memory impairment, and lethargy, have been described in less than $20 \%$ of subjects. It has been hypothesized that these symptoms could be caused by toxic metabolites derived from sugar and amino acid fermentation [50]. It is noteworthy that, out of these two types of fermentation, carbohydrate fermentation is linked predominantly to metabolic benefits of the host, whereas the more distal colonic fermentation of peptides and proteins is more closely associated with the production of harmful metabolites [53].

Although lactose maldigestion has been proposed as a factor involved in functional gastrointestinal disorders (FGIDs) [54-59], no conclusive evidence for a direct relation has been shown $[4,26,60,61]$. In order to address lactose intolerance (maldigestion) and associated (clinical and nutritional) issues, lactose replacement and restriction strategies have widely received attention. According to the CODEX Alimentarius [62], glucose polymers can replace lactose in infant formulae to meet the caloric requirements. Based on effects of glucose and sucrose overconsumption in children, it has been hypothesized that regular consumption of lactose substitutes in infant formulae may represent a potential risk factor for the development of overweight or obesity. The following paragraphs will address the various aspects involved in the diagnosis, functional consequences, and treatment of lactose intolerance. In addition, the short and long-term effects of lactose replacements on key physiological parameters will be highlighted.

\subsection{Diagnosis of Lactose Intolerance}

The incidence of lactose intolerance depends on the diagnostic method used and the amount of lactose used in the test. While a lactase activity assay in jejunal biopsies is the gold standard for diagnosis, the lactose hydrogen $\left(\mathrm{H}_{2}\right)$ and/or methane $\left(\mathrm{CH}_{4}\right)$ breath test is more practical and less invasive [63-65]. To discriminate between hydrogen and methane producers, and fast or slow fermenters, a pre-screening test with lactulose (always fermented) can be performed [66]. Finally, lactose exclusion or reduction (during 2-4 weeks) to achieve symptomatic improvement, followed by gradual lactose reintroduction, has proven useful and is often applied [66]. With regard to the dose of lactose used for intolerance tests, the commonly-used dose of $50 \mathrm{~g}$ may not be realistic, since 
this is the equivalent of 1 liter of milk, which is highly unlikely to be consumed at once in practice. Therefore, $25 \mathrm{~g}$ might represent a more suitable provocation dose, at least for adults [67]. An even better alternative might be the implementation of a dairy product tolerance test (e.g., drinking $250 \mathrm{~mL}$ of milk) with symptom evaluation up to 24 hours post-consumption and the inclusion of an $\mathrm{H}_{2} / \mathrm{CH}_{4}$ breath test $[68,69]$. For infants and children, a $\mathrm{H}_{2} / \mathrm{CH}_{4}$ breath test and elimination-provocation diets, using physiological doses ( $2 \mathrm{~g} / \mathrm{kg}$ of body weight) of lactose, are commonly used [4,60].

\subsection{Possible Consequences of Lactose Restriction}

Once lactose intolerance has been diagnosed, it is important to identify its severity and underlying cause. Most infants digest lactose very well and a lactose-restricted diet is only necessary for a limited period of time in case of transient lactase deficiency (due to, for instance, intestinal epithelial damage). In subjects with LNP (typically older children and adults), varied amounts of lactose are still tolerated without the presentation of significant symptoms. Generally, individuals with LNP can consume up to $12 \mathrm{~g}$ of lactose in a single dose with no or only minor intolerance symptoms $[5,70]$. In addition, the oral administration of $\beta$-galactosidase (exogenous lactase) can improve tolerance to lactose-containing foods [5]. In the absence of formal guidelines, the American Academy of Pediatrics and the National Institutes of Health published general recommendations for the management of lactose intolerance [60,71].

Currently, no data exist on the long-term effects of lactose restriction in children. However, since lactose is a unique and major carbohydrate in mammalian milk, the exclusion of lactose containing milk and dairy-derived products also implies a restriction of the other nutrients present in these products. Dairy products are important sources of bioavailable calcium, vitamin D (when added), and vitamin $B_{12}$, and, over time, lactose-restriction may induce insufficiency, potentially resulting in decreased bone mineral density, anemia, and neuropathy [5,72]. Overall, depending on the severity of intolerance symptoms, a temporary reduction in lactose can be beneficial; however, this is no reason to stop breastfeeding. As previously indicated, lactose maldigestion due to LNP develops in a major part $(65 \%-70 \%)$ of the global population from (late) childhood onwards and can, but certainly does not always, lead to symptoms of lactose intolerance.

\subsection{Lactose Maldigestion and Functional Gastrointestinal Disorders (FGIDs)}

Lactose maldigestion develops when the amount of ingested lactose exceeds the capacity of lactase activity. As indicated above, most infants and toddlers can properly digest lactose and the likelihood of lactose maldigestion without the presence of intestinal damage factors, such as infection or allergy, is very low. In addition, there is no robust evidence to suggest that infants and toddlers with FGIDs present lactose maldigestion $[4,26,60,61]$. Under specific circumstances, however, gasses produced during lactose fermentation can cause or worsen abdominal pain and distension $[4,60]$. In patients with irritable bowel syndrome and visceral hypersensitivity, a reduction of lactose and/or other carbohydrates of the FODMAP (fermentable oligosaccharides disaccharides monosaccharides and polyols) group has shown a significant reduction in abdominal pain and bloating [54-56]. It should be noted that the current explanation for the occurrence of FGIDs in children and adolescents is not that of a single-cause entity; FGIDs are recognized and identified by morphological and physiological abnormalities that often occur in combination with other morbidities, including motility disturbances, visceral hypersensitivity, altered immune function, altered microbiota composition and activity, and altered central nervous system processing [57]. Additionally, stool reducing substances, i.e., unabsorbed reducing sugars in the stool, are not associated with the occurrence of colic. In fact, they are frequently present in the stools of healthy infants, either fed with human milk or lactose-containing formula, under 10 weeks of age. The presence of reducing substances in the stool of infants fed with human milk is even four times higher than that of formula-fed infants, probably due to the presence of a substantial amount of human milk oligosaccharides $[26,61,73]$. In formulae, prebiotics may explain part of the reducing sugars, but the presence of some lactose cannot be excluded. Nevertheless, reducing sugars 
do not appear to be harmful or associated with FGIDs. Taken together, lactose should not be considered a hazardous nutrient [74].

\subsection{Lactose Replacements: Metabolic Consequences of Glucose Polymers}

In lactose-free or lactose-reduced infant formula, lactose is substituted by glucose polymers. The most common glucose polymers are digestible maltodextrins, glucose syrups, and dried glucose syrups; these glucose polymers are produced by the hydrolysis of different types of starches (corn, rice, or potato starch) $[75,76]$. Starch, maltodextrins, glucose, and lactose all have a similar energy value ( $4 \mathrm{kcal} / \mathrm{g})$, but differ in the rates of digestion and absorption. Glucose is immediately available for absorption, whereas starches, maltodextrins, and lactose need to first be digested by $\alpha$-amylase, maltase, and lactase, respectively [76]. Of note, the enzymatic digestion of maltodextrins occurs at a high rate, resulting in post-ingestion insulin responses comparable to pure glucose.

Glucose polymers have a higher glycemic index $(\mathrm{GI}=110)$ than lactose $(\mathrm{GI}=46)$, and as a result, induce a higher glycemic response. The low GI of lactose is primarily caused by the non-insulinogenic response to galactose. This could be a metabolic advantage compared to glucose polymers that cause a larger increase in plasma glucose and plasma insulin. For adults, this appears to be true; GI is a valid parameter to classify diets with regard to their preventative (low GI) or provoking (high GI) effect on diabetes, coronary heart disease, and likely obesity as well [77]. For children and adolescents, such (preventive) low GI benefits are still under discussion. A study in infants on the effects of consumption of lactose or corn syrup-containing formula did not reveal any differences in insulin or blood glucose levels (based on area under the curve) over a two-hour postprandial period. However, after two hours, the lactose group exhibited significantly higher glucose and insulin levels compared to breastfed and corn syrup-containing formula groups [78]. It is possible that the increased glucose levels (120 min postprandial) that were observed were partially due to both glycogenolysis (breakdown of (galactose-derived) glycogen) and gluconeogenesis $[79,80]$. Another study, using urinary C-peptide to creatine ratio as a stable marker of insulin secretion, showed a higher C-peptide secretion after the consumption of a corn-sugar based formula compared to a lactose based formula, indicating higher insulin levels in the former [81].

High blood glucose levels are involved in protein glycation, the non-enzymatic reaction between glucose (or other reducing sugars) and an amine group from free amino acids or proteins. Although initially, glycation of molecules is reversible, irriversible complexes, called advanced glycation endproducts (AGEs), are formed over time. AGEs accumulate with age and are linked to certain complications associated with diabetes, kidney disease, metabolic disorders, and degenerative diseases $[82,83]$. Regular consumption of considerable amounts of high GI carbohydrates, that substantially increase blood glucose levels, enhances the risk of AGE formation [84].

Limited evidence [85] suggests that maltodextrin, consisting of $\alpha-1,4$ and $\alpha-1,6$-linked D-glucose chains, may disrupt host-microbial dynamics in the gut when it escapes digestion, and may be associated with the promotion of Escherichia coli colonization. Furthermore, it was shown that in vitro cellular exposure to maltodextrin leads to impaired anti-bacterial responses, as demonstrated by the increased viability of intracellular Salmonella in macrophages and epithelial cells cultured in maltodextrin-supplemented media. Although the effect of maltodextrin on Salmonella clearance in macrophages was dose-dependent, any exposure was sufficient to increase bacterial viability [85]. In another animal study, it was recently shown that maltodextrin promotes endoplasmic reticulum stress in intestinal Goblet cells, which leads to mucus depletion and exacerbation of intestinal inflammation [86]. Therefore, when providing a lactose-free formula that contains maltodextrins, changes in microbiota should be carefully monitored to get more insight in this topic. It is of interest to note that the gut microbiota is increasingly recognized as an import part of our bodies and that changes, and the intestinal microbiota are linked to various physiological processes, including body weight management [87]. An increased Firmicutes/Bacteriodetes ratio and a reduced capacity to degrade carbohydrates to short-chain fatty acids is related to metabolic dysfunction of the host organism [88]. 
This also highlights the importance of maximizing efforts (via, e.g., low heat treatment) to limit glycation of proteins during the production process of products containing proteins and reducing sugars (such as lactose). These food-derived glycated proteins may contribute to overall obesity risk, as the majority are not digested but fermented [83].

With regard to minerals, lactose is known to enhance the absorption and retention of calcium, magnesium, and manganese; this is related to a $\mathrm{pH}$ drop due to its fermentation in the large intestine, which increases solubility of calcium (and other minerals), thereby increasing passive absorption. However, the functional relevance of this increased absorption is questionable, considering the surplus of calcium that is typically added to formulae designed for infants and young children [13].

Ultimately, the risk of detrimental long-term effects on health due to providing high GI carbohydrates early in life should be carefully considered; replacement of lactose with glucose polymers might lead to a worse nutritional status, a change in intestinal microbiota, and reduced calcium absorption. The effects of lactose-containing or lactose-free formula on insulin and glucose levels in infants is less clear and largely inconclusive. Evidence for short-term effects on parameters linked to chronic diseases is very limited. However, since nutritional preferences are shaped during childhood, the long-term relevance of early exposure to sweet, high GI food products may be considerable $[77,82]$.

\subsection{Lactose Replacements: Taste Preference and Obesity Risk Later in Life}

Behavioral studies have indicated that in the last trimester of pregnancy, the taste buds are able to detect and send information to the central nervous system regarding the composition of the amniotic fluid, which illustrates that the development of the taste sense occurs at a very early stage in life. Similarly, it has been shown that at birth, children have a preference for sweet flavors, including carbohydrates in breast milk, which allows them to identify the sources of energy necessary for growth [89]. This preference for sweet flavors persists during childhood and adolescence and can potentially be a disadvantage in view of the obesogenic environment in which we live. Indeed, the availability and consumption of a large number of industrialized products, including sugary drinks, has been associated with the development of overweight and obesity in children and adolescents [90]. Interestingly, the sweetening effect of lactose is weak and devoid of any neurochemical stimulation (e.g., lactose does not evoke rewarding effects) [91]. The lack of a neurochemical response may explain why feelings of pain in infant rats are suppressed by glucose, sucrose, and fructose, but not by lactose [92]. The pain-reducing properties of sucrose have been replicated in human newborns [93].

The use of infant formulae as substitutes for breast milk is increasingly common, particularly in countries like Mexico, where parts of the population have abandoned the practice of breastfeeding and the recommendations of the WHO [94]. Infant formulae are often subject to several modifications, such as the hydrolysis of proteins, or the partial or total replacement of lactose with other carbohydrates, such as maltodextrins, glucose syrups, and even sucrose [95]. Like many other countries in the world, Mexico suffers from an epidemic of overweight and obesity amongst children and adolescents (prevalence of around 35\%). Although the taste for sweet flavors is innate (at least to some extent), it has also been pointed out that regular consumption of sweetened foods and drinks can have adverse short and long-term consequences on food preference and lead to the consumption of excessive amounts of sugar [96]. Unfortunately, a lot of uncertainty exists regarding the regular consumption of formulae with lactose substitutes due to a shortage of literature on this topic. Thus, at this time, it cannot be affirmed that regular consumption of infant formulae containing lactose replacers is a risk factor for the development of overweight or obesity. Studies comparing regular consumption of these formulae to consumption of other foods are warranted. Eventually, assessing if the accumulation of adipose tissue differs between children who consume infant formulae with and without lactose would be of great value. It should be noted that, besides the potential differential effects of lactose and lactose substitutes on food preference, lactose possesses other properties that can contribute to healthy body weight development. Lactose has a low GI, a property that has been shown to play a subtle role in 
the prevention or treatment of childhood obesity [77]. Furthermore, if undigested lactose reaches the lower intestine, the fermentation of lactose generates short-chain fatty acids that have been shown to regulate body weight through effects on food intake and energy metabolism [97]. Recently, partial replacement of glucose with galactose, resulting in a 1:1 ratio mimicking lactose, in a 3-week post weaning diet, was shown to lower body weight, adiposity, homeostatic model assessment of insulin resistance (HOMA-IR), and expression of insulin signaling in high fat diet-challenged female mice in later life. These findings suggest that prolonged galactose intake may improve metabolic and overall health for extended periods of time through galactose-mediated nutritional programming [98].

\subsection{Potential Health Benefits of Lactose as a Supplier of Galactose and via Microbiota Shaping Effects}

The gastrointestinal tract is colonized by different microorganisms, which participate in the mucosal immune system through diverse mechanisms [99]. Although the GI tract microbiota's composition, origin and abundances are controversial, evidence suggests that important microbiota-shaping factors include the maternal microbiota (oral, intestinal, and vaginal), circumstances and inoculation at birth (hospital, home, and normal versus caesarean delivery), anti-biotic treatment, and food (milk) composition. In addition, the period preceding delivery may be important, since bacteria seem to be present in the placenta, amniotic fluid, and meconium [100-102]. Gut microbiota and the host have a symbiotic relationship, with the former strengthening the immune system and protecting the host against pathogens [102]. Qualitative and quantitative changes in the intestinal microbiota, its metabolic activity, and its local distribution, affect pathobionts and pathogens in the gut, a state known as "dysbiosis." These changes could contribute to the development of diseases, such as colorectal cancer, gastrointestinal disorders, obesity, allergy, and others [102-106]. Recently, the genus Bifidobacterium has gained growing interest as it has been associated with the presence of undigested lactose and several health benefits [104]. Other factors, such as stress, diet, and genetic background, may also impact Bifidobacterium prevalence in the gut [107]. In the next paragraphs, we will discuss our current knowledge on the (potential beneficial) effects of (undigested) lactose on Bifidobacteria and the microbiota in total. In addition, the specific relevance of galactose downstream of lactose in glycogen synthesis and possibly as an important building block for glycosylation will be addressed as well.

\subsection{Lactose, Bifidobacteria, and the Microbiota: Potential Health Benefits?}

Breast milk is essential in infancy because it supplies important biomolecules, including oligosaccharides, antioxidants, IgA, and anti-inflammatory compounds, that offer protection against diseases [105]. As indicated previously, lactose is normally cleaved into the monosaccharides glucose and galactose by lactase in the GI tract [67]. However, if undigested, lactose reaches the terminal ileum and colon (as explained earlier), and it is fermented by the intestinal microbiota, favoring colonization by Bifidobacteria and other lactic acid bacteria. Additionally, in vitro studies have revealed that lactose increases the levels of gastrointestinal antimicrobial peptides. The colonization of Bifidobacteria and the induction of antimicrobial peptides both potentially protect, albeit independently, the neonatal gut against infection [31]. In LNP subjects (lactase $<10 \mathrm{u} / \mathrm{g}$ ) and in infants that are physiological malabsorbers of lactose, lactose can exert microbiota-modulating effects as well $[8,9,108]$.

Lactose is fermented by members of the microbiota that can easily split the $\beta-1,4$-glycosidic linkage. Studies in weaning pigs show a positive, dose-related effect of dietary supplementation with lactose on intestinal Bifidobacteria and Lactobacilli, and an increase in total volatile fatty acids in feces with a particular increase in butyric acid [109]. In infants, the addition of lactose (38 g/L) to an extensively hydrolyzed formula resulted in significantly augmented counts of Bifidobacteria and lactic acid bacteria, and decreased numbers of Bacteroides and Clostridia compared to a lactose-free variant. The same study also demonstrated a positive effect of added lactose on the fecal metabolome with increased concentrations of short-chain fatty acids (mainly acetic and butyric acid) [110]. In young adults with lactose malabsorption (as indicated by increased exhaled hydrogen levels), whole milk supplementation ( $250 \mathrm{~mL} /$ day, during 4 weeks) resulted in a higher relative abundance of fecal 
Actinobacteria, Bifidobacteria, Anaerostipes (butyrate producers), and Blautia (acetogenic) compared to normal lactose digesters [111]. Next to lactose, human milk oligosaccharides (HMO) are well-known stimulators of the neonatal intestinal microbiota [112]. Additionally, prebiotics in infant formulae show microbiota-shaping effects (i.e., an increase in Bifidobacteria up to levels seen in breastfed infants, accompanied by a smaller rise in Lactobacilli) $[113,114]$. Interestingly, galacto-oligosaccharide (GOS) supplementation appears to be beneficial for lactose-intolerant individuals $[115,116]$. Stimulation of both Bifidobacterium and Faecalibacterium activities ameliorated lactose-intolerance symptoms [117]. In fact, both a Bifidobacterium-rich fecal microbiota, associated with reduced lactose digestion, together with increased levels of short-chain fatty acids, exerted a protective effect on colonic mucosal integrity and early immune system development [118]. Less well-known fibers, such as fructans from Mexican Agave plants, may exhibit these microbiota-shaping effects as well and could support the proper fermentation of lactose [119].

As discussed earlier, lactose may also have immunomodulatory effects. Postpartum, infants do not have fully functional adaptive immune systems and rely on the innate immune system with its antimicrobial peptides and proteins expressed on epithelial surfaces. In vitro research suggests that lactose may be part of this early defense system. Lactose (supplied as the hydrophilic fraction of breast milk or as commercially-available purified lactose) induced, in vitro, the cathelicidin antimicrobial peptide $(C A M P)$ gene encoding the human antimicrobial peptide cathelicidin LL-37 in colonic epithelial cells in a dose and time-dependent manner. Lactose also induced CAMP in the colonic epithelial cell line T84, THP-1 monocytes, and macrophages. Furthermore, a synergistic effect on CAMP induction was demonstrated with butyrate and phenylbutyrate. Although infant formulae also showed a stimulation of CAMP, a dose-dependent effect was lacking [31]. These antimicrobial peptides, such as CAMP, might play a role in further shaping the neonatal microbiota [12].

Many of the proposed beneficial effects of lactose can be linked to short-chain fatty acids that (1) serve locally as energy for the gut microbiota and the cells of the intestinal wall, (2) confer a protective effect on colonic mucosal integrity, (3) exert a beneficial effect on early immune development, and (4) are used as energy source following absorption and transport to the liver [31,120]. Overall, it appears that lactose can beneficially influence the gut microbiota and play a role in the development of Bifidobacteria in the guts of LNP individuals, infants, and children. Interestingly, Bifidobacteria metabolize lactose to short chain fatty acids and lactate, but not $\mathrm{H}_{2}$, whereas $\mathrm{H}_{2}$ can comprise up to $50 \%$ of the flatus volume [121]. Therefore, its consumption/supplementation, albeit in adequately sub-threshold doses with respect to lactose intolerance complaints, can lead to improved lactose tolerance.

\subsection{Potential Health Benefits of Galactose}

It seems unclear why nature designated lactose as the disaccharide to uniquely occur in mammalian milk; its synthesis requires substantial investment of energy by the mother, and the breastfed infant subsequently requires energy for its digestion. Part of the explanation could be that coupling of the two monosaccharides glucose and galactose, reduces the osmotic pressure of milk, which by definition is equal to the osmotic pressure of maternal plasma. Coupling allows for a higher mother-to-child transfer of a carbohydrates that serves as a slow-release energy source and a provider of building blocks for complex macromolecules in the infant. Following lactase-mediated hydrolysis of lactose in the infant's GI tract, both glucose and galactose are predominantly taken up by the sodium-glucose linked transporter-1 (SGLT1) [122,123]. This symporter also transports sodium and water, and co-transports calcium by bulk flow [124]. Unabsorbed lactose, as well as unabsorbed glucose and galactose moieties and HMOs may serve as substrates for the microbiota in the infant's colon [125]. Most of the absorbed glucose passes the liver to elicit an insulin response, which causes the majority of galactose to become trapped in the liver [126], where it becomes a major substrate for the synthesis of glycogen $[18,123,126]$. The glucose-mediated insulin-response enhances glycogen synthesis by inhibiting a kinase or kinases, such as glycogen synthase kinase-3 (GSK-3) [127], that inactivate glycogen synthase $[123,126,128]$. Although galactose is not considered an essential nutrient in general, it could 
be conditionally essential in infants in the context of rapid growth. Galactose is used for the synthesis of a variety of oligosaccharides, glycoproteins, and glycolipids [129]. Moreover, lactose-derived galactose could be important in assuring metabolic flexibility in infants/young children, because it behaves in a non-insulinogenic manner (under fed conditions), and thereby lifts the break (e.g. insulin) on fat metabolism [78]. This enables the infant to switch to fat metabolism (e.g., ketone body production) when there is a high demand for energy, for instance during rapid growth. Amongst others, ketone bodies are a great energy substrate for the brain, which is incapable of oxidizing fats itself.

Thus, lactose limits milk osmotic pressure, promotes uptake of sodium, water and calcium, and acts as a microbiota-modulating nutrient, partially as unabsorbed lactose, and partially as a source of building blocks for the more complex HMOs. Absorbed glucose and galactose serve as the foundation for macromolecules, a rapidly available energy source (glucose), and 'storage' in the form of mobilizable glycogen in the liver (generated from galactose) [18].

\subsection{Consensus Statements}

The participants of the consensus meeting adopted the following statements:

Lactose does not differ in biochemical-structural composition between mammalian milks, and it is a unique carbohydrate in nature with beneficial properties in most people.

Lactase activity is detectable in the fetal gut by eight weeks of gestation; and at least from 32 weeks of gestational age onwards until late childhood or longer, lactose $(6-7 \mathrm{~g} / 100 \mathrm{~mL})$ can be digested sufficiently.

Lactase expression in case of primary, adult-onset lactase deficiency, does not stop at a precise moment in time: its down-regulation is the result of an incompletely understood, internal, epigenetic developmental program.

Lactase persistency is a very strongly and positively selected genetic trait that significantly increased survival rates after it arose, amongst others, by improving daily nutrition. Nowadays, approximately $35 \%$ of the world's population is lactase persistent.

Lactose maldigestion (any undigested lactose) is not a clinically relevant issue in infants and children, unless symptoms of lactose intolerance or symptoms related to GI diseases, such as celiac or Crohn's disease, are severe.

Lactose maldigestion is not a harmful process when the dose does not exceed the fermentation capacity of the intestine and is not related to functional gastrointestinal disorders.

Lactase non-persistent children and adults still can consume lactose without symptoms of intolerance but the tolerable amounts are variable and depend on several factors. It is said that up to 12 grams of lactose in a single dose is well tolerated, and when combined with a meal and/or distributed over the day, even higher amounts are well tolerated by many maldigesters.

Lactose contributes to the development of a Bifidobacteria-rich microbiota and may act as a microbiota-shaping carbohydrate especially in LNP persons but also in LP infants and children.

Dietary galactose, in combination with glucose (simultaneously delivered to the body, in the case of lactose), plays an important role in infant's and children's nutrition in the replenishment of liver glycogen.

Exogeneous galactose supply (e.g., via lactose) may be needed under conditions of growth and development (e.g., infants and young children) as a structural building block for glycosylated macromolecules (e.g., galactocerebrosides for myelination by oligodendrocytes in the brain).

The consumption of high GI maltodextrins and the consecutive rise in blood glucose levels may not be favorable for infants and children in the long run because of its impact on inflammatory pathways.

Lactose is preferred over lactose replacers in infant's and children's nutrition because of its weak sweet taste and the fact that lactose consumption does not elicit any rewarding effects. Lactose could, therefore, lead to less imprinting of sweet taste at a young age, and therefore, reduce the preference for sweet flavors later in life. 
The potentially beneficial impact of lactose on overweight development in children is at the moment, not scientifically validated. Specifically-designed longitudinal scientific studies are needed to clarify this potential link.

\section{Discussion}

Lactose, synthesized in the mammary gland, is nature's way to get a significant quantity of carbohydrates in milk, and largely determines the volume of milk produced and provides a relevant portion of slow-release energy [17]. Since lactose is the primary carbohydrate in most mammalian milks and its concentration in milk cannot be influenced by the maternal diet, it is obvious that lactose is the preferred carbohydrate in infant and young child formulae. However, the use of lactose-reduced or lactose-free formulae in several countries is increasing. The main driver for this is the often-false coupling of symptoms of intestinal discomfort to (perceived) lactose intolerance. From childhood onwards, lactose maldigestion is established in the majority of the world's population because of a genetically-driven down-regulation of lactase expression (LNP) [3,32]. The proposed benefits of lactose (energy source without rewarding effects, supplier of galactose and glucose, low GI, microbiota-modulating activity, and low carcinogenicity) $[8-11,20,21]$ necessitate a careful, well thought-out approach for managing lactose maldigestion. During this workshop, the attendees discussed the available evidence for the proposed benefits of lactose, the clinical aspects of lactose intolerance, and the importance of lactose for infants, children, and adults, both in the context of LNP and LP. This resulted in the drafting of the 13 statements presented in this document (see Section 3.14. Consensus Statements).

When lactose is digested, the absorbed glucose passes the liver to elicit an insulin response, which causes the majority of galactose to become trapped in the liver [126], acting as a major substrate for the synthesis of liver glycogen $[18,123,126]$. Any toxic effects of galactose, as supplied by lactose, are neglectable. Even after the ingestion of $100 \mathrm{~g}$ of lactose, the maximum concentration of galactose in the systemic circulation stays $\leq 1 \mathrm{mmoL} / \mathrm{L}$ [79]. Taking into account that the maximal recommended daily dose of galactose is $50 \mathrm{~g}$ for a healthy adult, liver galactose clearance capacity appears to be high enough under normal circumstances [130]. However, the ingestion of galactose without glucose or with alcohol consumption induces higher, non-pathological plasma concentrations of galactose [79]. In the liver, galactose is converted by the enzyme galactokinase into galactose-1-phosphate, which is converted into uridine diphosphate (UDP)-galactose, UDP-glucose, and next into glycogen, or it is transformed into glucose-1-phosphate $[79,80,131]$. Pathologically elevated blood galactose levels may occur because of deficient functioning of enzymes involved in galactose metabolism (e.g., GALK (galactokinase), GALT (galactose-1-phosphate uridyl transferase), or UDP-Galactose-4 epimerase (GALE)), a rare condition known as galactosemia [132]. Individuals suffering from this disease accumulate certain galactose metabolites (galactitol and galactose-1-phosphate) leading to damage of the eye lens, liver, kidneys, and brain. As a source of glucose, liver glycogen can restore postprandial blood glucose levels when these become too low. Although galactose is also used for the synthesis of a variety of oligosaccharides, glycoproteins, and glycolipids [129], it is not known to what extent dietary galactose is used for this. At least in adults, the use of dietary galactose seems to be limited and most galactose is produced endogenously from glucose. This is not, per se, the case in infants and young children since they have much higher growth-related demands. Lactose intake has been indicated to favor brain function in children; however, it is not clear if this can be directly linked to the systemic galactose availability [133]. Lactose-derived galactose could be important in assuring the metabolic flexibility required in infants/young children, because it acts in a non-insulinogenic way (under fed conditions), and thereby lifts the ban (i.e., insulin) on fat metabolism [78]. Additionally, for adults, the non-insulinogenic characteristic of lactose-derived galactose can be of interest in light of metabolic health.

An often-mentioned benefit of lactose is its low glycemic index (GI). There is convincing evidence from meta-analyses of controlled dietary trials that diets low in GI improve glycemic control in 
people with type 2 and type 1 diabetes. There is also convincing evidence from meta-analysis of prospective cohort studies that low GI/GL diets reduce the risk of developing type 2 diabetes [77]. Consumption of lactose-containing dairy products is neutral or moderately beneficial to type 2 diabetes risk [134]. Dairy consumption is sometimes linked to an increased type 1 diabetes risk, especially in young children at risk (genetic predisposition for type 1 diabetes). Mechanistically, this is linked to dairy proteins, specifically to A1 $\beta$-casein and its seven amino acid peptide $\beta$-casomorphin-7 (BCM-7) derivative, but not to lactose. The ecological relationship of milk A1 $\beta$-casein with type 1 diabetes across populations is strong. However, a causal role in its own right is unlikely [135]. There is a similar relationship with vitamin D status, for which the putative mechanistic background in (auto)immune disease is plausible [136,137]. Given the association of low vitamin D status with many other immunologically-driven diseases, it seems possible that in the etiology of type 1 diabetes mellitus, a low vitamin D phenotype interacts with A1 $\beta$-casein/BCM-7 or some other antigen(s), to which the gut mucosa is exposed in early life. Interference with mucosal tolerance might be key. Recently, an international, randomized clinical trial in 2159 infants at risk to present the disease, randomly assigned to the consumption of a formula based on extensively hydrolyzed casein versus a formula with intact milk protein, found no difference between groups in the incidence of type 1 diabetes after a median follow-up of 11.5 years [138].

Lactose maldigestion is a result of too much lactose relative to lactase capacity. Lactase expression reaches mature levels around term age [27-29]; this means that newborns and young children can digest physiological amounts of lactose (i.e., as present in breastmilk) without any problems. Only when they have no or low lactase expression due to congenital lactase deficiency, gastrointestinal infections, or to preterm birth, can the digestion of lactose be compromised. Although LNP children and adults have a considerably limited capacity to digest lactose, most of them should be able to deal with the fermentation of $12 \mathrm{~g}$ of lactose in a single dose without having any relevant symptoms of lactose intolerance $[5,70]$. In about $35 \%$ of the world's population, lactose can be digested, as lactase expression is continuous (LP) due to SNPs that prevent the epigenetic silencing of lactase after weaning. No conclusive evidence is available for a direct relationship between lactose intolerance and FGIDs [4,26,60,61]. Exclusion of lactose containing milk and derived dairy products also implies a restriction in the intake of other nutrients present in these products.

Widely-used glucose polymers in lactose-free infant formulae are digestible maltodextrins and glucose syrups. Additionally, sucrose is sometimes used. It is unclear if these lactose replacements are nutritionally equivalent to lactose, except regarding calories. When comparing lactose to sucrose, various differences can be observed: (1) lactose contains glucose and galactose, while sucrose contains glucose and fructose. Galactose and fructose have different metabolic behaviour inside the body; (2) lactose contains a $\beta 1$,4-glycosidic linkage, while sucrose contains an $\alpha 1,2$-glycosidic bond; (3) the GI of lactose is 46 , while the GI of sucrose is 65 ; (4) lactose has low sweetness and lacks rewarding effects after consumption, while sucrose possesses high sweetness and elicits rewarding effects; (5) lactose contains the versatile monosaccharide galactose which sucrose lacks; (6) lactose is less cariogenic than sucrose; and (7) lactose exerts gut-microbiota-modulating effects that lead to increased uptake of calcium, an effect not found for sucrose. Limited evidence suggests that maltodextrin is also not equivalent to lactose. Maltodextrin, consisting of $\alpha-1,4$ and $\alpha-1,6$-linked D-glucose chains, may disrupt host-microbial dynamics in the gut when it escapes digestion, and may be associated with the promotion of E. coli colonization. A decision to replace lactose should take these differences into account.

\section{Conclusions}

Lactose is the preferred carbohydrate for infants and young children, for reasons that it (1) acts as an excellent, slow release, energy source; (2) possibly contributes (in infants) to the synthesis of complex glycosylated macromolecules by the provision of the building blocks glucose and galactose; (3) elicits no reward effects after consumption; (4) has a low cariogenic effect (not discussed in this paper); and (5) exerts gut microbiota-shaping effects, most likely promoting a more saccharolytic than 
proteolytic microbiota. Though some degree of lactose maldigestion will take place in all infants and young children, this will seldomly lead to lactose intolerance symptoms. Additionally, in in LNP adults and older children, dose-dependent fermentation of lactose takes place without symptoms of intolerance almost always, while providing all the benefits of this fermentation. Considering all above-mentioned benefits, the replacement of lactose by other carbohydrates has to be considered with care and moderation.

Author Contributions: E.R.-V. chaired the consensus meeting, was one of the presenters, and was involved in writing the final manuscript. D.D.-F., M.G.-G., C.G.-D., A.L.-H., E.M.-B., F.A.J.M., B.V.-G., and J.G. were presenters during the meeting and/or wrote extended abstracts of the presentations. J.G. was also involved in writing the final manuscript. All reviewed the final manuscript and agreed upon the content and the final statements.

Funding: The meeting took place at Tequisquiapan, Queretaro, Mexico. All participants received support for travel and accommodation. Related costs for support and the venue were also paid by FrieslandCampina.

Acknowledgments: The authors really appreciate the contributions of the workshop participants: José Diego Benavides Hernandez, Maricela Hernández Robles, Roberto Calva Rodriguez, Vanessa Hernández Rosiles, Armando Cruz Rodriguez, Ulises Leal Quiroga, Sergio Diaz Madero, Oscar Augusto Maldonado Vergara, Laura Flores Fong, Maria Teresa Medina Durón, Raúl Garza Bulnes, Carlos Meza Lopez, Roberto González Galván, Salvador Villalpando Carreón, Perla González Rodríguez, Carlos Alberto García Bueno, Guillermina Gómez Navarro. Furthermore, we would like to thank Cordula Lindner, Glenn van Lieshout, Arjen Nauta, and Anne Schaafsma for their help in writing the manuscript, and Miriam Contreras for organizing the meeting. Finally, compilation and language editing were performed by Science Impact, Winnipeg, Canada; www.science-impact.company.

Conflicts of Interest: The authors declare no conflict of interest.

\section{References}

1. Meurant, G. Handbook of Milk Composition, Chapter 4. Carbohydrates in Milks: Analysis, Quantities, and Significance. Food Sci. Technol. 1995, 6, 273-338.

2. Paques, M.; Lindner, C. Lactose. Evolutionary Role, Health Effects, and Applications; Academic Press: Cambridge, MA, USA, 2019; ISBN 978-0-12-811720-0.

3. Campbell, A.K.; Waud, J.P.; Matthews, S.B. The molecular basis of lactose intolerance. Sci. Prog. 2005, 88, 157-202. [CrossRef] [PubMed]

4. Vandenplas, Y. Lactose intolerance. Asia Pac. J. Clin. Nutr. 2015, 24, S9-S13. [PubMed]

5. Canani, R.B.; Pezzella, V.; Amoroso, A.; Cozzolino, T.; Di Scala, C.; Passariello, A. Diagnosing and treating intolerance to carbohydrates in children. Nutrients 2016, 8, 157. [CrossRef] [PubMed]

6. Bersaglieri, T.; Sabeti, P.C.; Patterson, N.; Vanderploeg, T.; Schaffner, S.F.; Drake, J.A.; Rhodes, M.; Reich, D.E.; Hirschhorn, J.N. Genetic signatures of strong recent positive selection at the lactase gene. Am. J. Hum. Genet. 2004, 74, 1111-1120. [CrossRef] [PubMed]

7. Curry, A. The milk revolution. Nature 2013, 500, 20-22. [CrossRef] [PubMed]

8. Szilagyi, A. Lactose-a potential prebiotic. Aliment. Pharmacol. Ther. 2002, 16, 1591-1602. [CrossRef] [PubMed]

9. Szilagyi, A. Redefining lactose as a conditional prebiotic. Can. J. Gastroenterol. 2004, 18, 163-167. [CrossRef] [PubMed]

10. Schaafsma, G. Lactose and lactose derivatives as bioactive ingredients in human nutrition. Int. Dairy J. 2008, 18, 458-465. [CrossRef]

11. Delaveau, P. Le lactose dans le lait; hypothese sur son importance biologique. Ann. Pharm. Fr. 2002, 61, $340-342$.

12. Salzman, N.H.; Underwood, M.A.; Bevins, C.L. Paneth cells, defensins, and the commensal microbiota: A hypothesis on intimate interplay at the intestinal mucosa. Semin. Immunol. 2007, 19, 70-83. [CrossRef] [PubMed]

13. Abrams, S.A.; Griffin, I.J.; Davila, P.M. Calcium and zinc absorption from lactose-containing and lactose-free infant formulas. Am. J. Clin. Nutr. 2002, 76, 442-446. [CrossRef] [PubMed]

14. Gaffey, M.F.; Wazny, K.; Bassani, D.G.; Bhutta, Z.A. Dietary management of childhood diarrhea in low- and middle-income countries: A systematic review. BMC Public Health 2013, 13, S17. 
15. Sherman, A.L.; Anderson, J.; Rudolph, C.D.; Walker, L.S. Lactose-Free milk or soy-based formulas do not improve caregivers' distress or perceptions of difficult infant behavior. J. Pediatr. Gastroenterol. Nutr. 2015, 61, 119-124. [CrossRef] [PubMed]

16. Zunft, H.J.; Schulze, J. Does mutarotation influence lactose digestion? Experimental investigations and a mathematical model. Comput. Methods Programs Biomed. 1990, 32, 287-295. [CrossRef]

17. Holt, C. Swelling of golgi vesicles in mammary secretory cells and its relation to the yield and quantitative composition of milk. J. Theor. Biol. 1983, 101, 247-261. [CrossRef]

18. Coelho, A.I.; Berry, G.T.; Rubio-Gozalbo, M.E. Galactose metabolism and health. Curr. Opin. Clin. Nutr. Metab. Care 2015, 18, 422-427. [CrossRef] [PubMed]

19. Moynihan, P.J. Dietary advice in dental practice. Br. Dent. J. 2002, 193, 563-568. [CrossRef] [PubMed]

20. Gunnerud, U.; Holst, J.J.; Stman, E.; Björck, I. The glycemic, insulinemic and plasma amino acid responses to equi-carbohydrate milk meals, a pilot-study of bovine and human milk. Nutr. J. 2012, 11, 83. [CrossRef] [PubMed]

21. Schuette, S.A.; Knowles, J.B.; Ford, H.E. Effect of lactose or its component sugars on jejunal calcium absorption in adult man. Am. J. Clin. Nutr. 1989, 50, 1084-1087. [CrossRef] [PubMed]

22. Troelsen, J.T. Adult-type hypolactasia and regulation of lactase expression. Biochim. Biophys. Acta-Gen. Subj. 2005, 1723, 19-32. [CrossRef] [PubMed]

23. Lenfestey, M.W.; Neu, J. Gastrointestinal development: Implications for management of preterm and term infants. Gastroenterol. Clin. N. Am. 2018, 47, 773-791. [CrossRef] [PubMed]

24. Raul, F.; Lacroix, B.; Aprahamian, M. Longitudinal distribution of brush border hydfolases and morphological maturation in the intestine of the preterm infant. Early Hum. Dev. 1986, 13, 225-234. [CrossRef]

25. Antonowicz, I.; Lebenthal, E. Developmental pattern of small intestinal enterokinase and disaccharidase activities in the human fetus. Gastroenterology 1977, 72, 1299-1303. [PubMed]

26. Weaver, L.T.; Laker, M.F.; Nelson, R. Neonatal intestinal lactase activity. Arch. Dis. Child. 1986, 61, 896-899. [CrossRef] [PubMed]

27. Neu, J. Gastrointestinal maturation and implications for infant feeding. Early Hum. Dev. 2007, 83, 767-775. [CrossRef] [PubMed]

28. de Vrese, M.; Sieber, R.; Stransky, M. Lactose in human nutrition. Schweiz. Med. Wochenschr. 1998, 128, 1393-1400. [PubMed]

29. Tan-Dy, C.R.Y.; Ohlsson, A. Lactase treated feeds to promote growth and feeding tolerance in preterm infants. Cochrane Database Syst. Rev. 2013. Art. No.: CD004591. [CrossRef] [PubMed]

30. Shulman, R.J.; Schanler, R.J.; Lau, C.; Heitkemper, M.; Ou, C.N.; Smith, E.O. Early feeding, feeding tolerance, and lactase activity in preterm infants. J. Pediatr. 1998, 133, 645-649. [CrossRef]

31. Cederlund, A.; Kai-Larsen, Y.; Printz, G.; Yoshio, H.; Alvelius, G.; Lagercrantz, H.; Stromberg, R.; Jornvall, H.; Gudmundsson, G.H. Lactose in human breast milk an inducer of innate immunity with implications for a role in intestinal homeostasis. PLoS ONE 2013, 8, e53876. [CrossRef] [PubMed]

32. Leseva, M.N.; Grand, R.J.; Klett, H.; Boerries, M.; Busch, H.; Binder, A.M.; Michels, K.B. Differences in DNA methylation and functional expression in lactase persistent and non-persistent individuals. Sci. Rep. 2018, 8 , 5649. [CrossRef] [PubMed]

33. Gerbault, P.; Liebert, A.; Itan, Y.; Powell, A.; Currat, M.; Burger, J.; Swallow, D.M.; Thomas, M.G. Evolution of lactase persistence: An example of human niche construction. Philos. Trans. R. Soc. B Biol. Sci. 2011, 366, 863-877. [CrossRef] [PubMed]

34. Ingram, C.J.E.; Mulcare, C.A.; Itan, Y.; Thomas, M.G.; Swallow, D.M. Lactose digestion and the evolutionary genetics of lactase persistence. Hum. Genet. 2009, 124, 579-591. [CrossRef] [PubMed]

35. Itan, Y.; Powell, A.; Beaumont, M.A.; Burger, J.; Thomas, M.G. The origins of lactase persistence in Europe. PLoS Comput. Biol. 2009, 5, e1000491. [CrossRef] [PubMed]

36. Nielsen, R.; Hellmann, I.; Hubisz, M.; Bustamante, C.; Clark, A.G. Recent and ongoing selection in the human genome. Nat. Rev. Genet. 2007, 8, 857-868. [CrossRef] [PubMed]

37. Tishkoff, S.A.; Reed, F.A.; Ranciaro, A.; Voight, B.F.; Babbitt, C.C.; Silverman, J.S.; Powell, K.; Mortensen, H.M.; Hirbo, J.B.; Osman, M.; et al. Convergent adaptation of human lactase persistence in Africa and Europe. Nat. Genet. 2007, 39, 31-40. [CrossRef] [PubMed] 
38. Evershed, R.P.; Payne, S.; Sherratt, A.G.; Copley, M.S.; Coolidge, J.; Urem-Kotsu, D.; Kotsakis, K.; Özdoğan, M.; Özdoğan, A.E.; Nieuwenhuyse, O.; et al. Earliest date for milk use in the Near East and Southeastern Europe linked to cattle herding. Nature 2008, 455, 528-531. [CrossRef] [PubMed]

39. Makarewicz, C.; Tuross, N. Finding fodder and tracking transhumance: Isotopic detection of goat domestication processes in the Near East. Curr. Anthropol. 2012, 53, 495-505. [CrossRef]

40. Helmer, D.; Vigne, J.-D. Was milk a "secondary product" in the Old World Neolithisation process? Its role in the domestication of cattle, sheep and goat. Europe 2007, 42, 9-40.

41. Amiri, M.; Diekmann, L.; von Köckritz-Blickwede, M.; Naim, H.Y. The diverse forms of lactose intolerance and the putative linkage to several cancers. Nutrients 2015, 7, 7209-7230. [CrossRef] [PubMed]

42. Jones, B.L.; Swallow, D.M. The impact of cis-acting polymorphisms on the human phenotype. Hugo J. 2011, 5, 13-23. [CrossRef] [PubMed]

43. Labrie, V.; Buske, O.J.; Oh, E.; Jeremian, R.; Ptak, C.; Gasinas, G.; Maleckas, A.; Petereit, R.; Avirbliene, A.; Adamonis, K.; et al. Lactase nonpersistence is directed by DNA-variation-dependent epigenetic aging. Nat. Struct. Mol. Biol. 2016, 23, 566-573. [CrossRef] [PubMed]

44. Swallow, D.M.; Troelsen, J.T. Escape from epigenetic silencing of lactase expression is triggered by a single-nucleotide change. Nat. Struct. Mol. Biol. 2016, 23, 505-507. [CrossRef] [PubMed]

45. Ranciaro, A.; Campbell, M.C.; Hirbo, J.B.; Ko, W.Y.; Froment, A.; Anagnostou, P.; Kotze, M.J.; Ibrahim, M.; Nyambo, T.; Omar, S.A.; et al. Genetic origins of lactase persistence and the spread of pastoralism in africa. Am. J. Hum. Genet. 2014, 94, 496-510. [CrossRef] [PubMed]

46. Hauri, H.P.; Sander, B.; Naim, H. Induction of lactase biosynthesis in the human intestinal epithelial cell line Caco-2. Eur. J. Biochem. 1994, 219, 539-546. [CrossRef] [PubMed]

47. Lee, S.Y.; Madan, A.; Furuta, G.T.; Colgan, S.P.; Sibley, E. Lactase gene transcription is activated in response to hypoxia in intestinal epithelial cells. Mol. Genet. Metab. 2002, 75, 65-69. [CrossRef] [PubMed]

48. Lev, R.; Bender, M.S.; Appleton, H.D. The biochemical and histochemical demonstration of lactase induction in fetal rat intestine by intra-amniotic injection of lactose. Histochemistry 1979, 61, 255-262. [CrossRef] [PubMed]

49. Venema, K. Intestinal fermentation of lactose and prebiotic lactose derivatives, including human milk oligosaccharides. Int. Dairy J. 2012, 22, 123-140. [CrossRef]

50. Campbell, A.K.; Matthews, S.B.; Vassel, N.; Cox, C.D.; Naseem, R.; Chaichi, J.; Holland, I.B.; Green, J.; Wann, K.T. Bacterial metabolic "toxins": A new mechanism for lactose and food intolerance, and irritable bowel syndrome. Toxicology 2010, 278, 268-276. [CrossRef] [PubMed]

51. Robayo-Torres, C.C.; Nichols, B.L. Molecular differentiation of congenital lactase deficiency from adult-type hypolactasia. Nutr. Rev. 2007, 65, 95-98. [CrossRef] [PubMed]

52. Uchida, N.; Sakamoto, O.; Irie, M.; Abukawa, D.; Takeyama, J.; Kure, S.; Tsuchiya, S. Two Novel mutations in the lactase gene in a Japanese infant with congenital lactase deficiency. Tohoku J. Exp. Med. 2012, 227, 69-72. [CrossRef] [PubMed]

53. Canfora, E.E.; Meex, R.C.R.; Venema, K.; Blaak, E.E. Gut microbial metabolites in obesity, NAFLD and T2DM. Nat. Rev. Endocrinol. 2019, 15, 261-273. [CrossRef] [PubMed]

54. Chumpitazi, B.P.; Hollister, E.B.; Oezguen, N.; Tsai, C.M.; McMeans, A.R.; Luna, R.A.; Savidge, T.C.; Versalovic, J.; Shulman, R.J. Gut microbiota influences low fermentable substrate diet efficacy in children with irritable bowel syndrome. Gut Microbes 2014, 5, 165-175. [CrossRef] [PubMed]

55. Chumpitazi, B.P.; Cope, J.L.; Hollister, E.B.; Tsai, C.M.; McMeans, A.R.; Luna, R.A.; Versalovic, J.; Shulman, R.J. Randomised clinical trial: Gut microbiome biomarkers are associated with clinical response to a low FODMAP diet in children with the irritable bowel syndrome. Aliment. Pharmacol. Ther. 2015, 42, 418-427. [CrossRef] [PubMed]

56. Altobelli, E.; Del Negro, V.; Angeletti, P.M.; Latella, G. Low-FODMAP diet improves irritable bowel syndrome symptoms: A meta-analysis. Nutrients 2017, 9, E940. [CrossRef] [PubMed]

57. Drossman, D.A. Functional gastrointestinal disorders: History, pathophysiology, clinical features, and Rome IV. Gastroenterology 2016, 150, 1262-1279.e2. [CrossRef] [PubMed]

58. Benninga, M.A.; Nurko, S.; Faure, C.; Hyman, P.E.; St James Roberts, I.; Schechter, N.L. Childhood functional gastrointestinal disorders: Neonate/toddler. Gastroenterology 2016, 150, 1443-1455.e2. [CrossRef] [PubMed]

59. Hyams, J.S.; Di Lorenzo, C.; Saps, M.; Shulman, R.J.; Staiano, A.; Van Tilburg, M. Childhood functional gastrointestinal disorders: Child/adolescent. Gastroenterology 2016, 150, 1456-1468.e2. [CrossRef] [PubMed] 
60. Heyman, M.B.; Care, P. Lactose intolerance in infants, children, and adolescents. Pediatrics 2006, 118, 1279-1286. [CrossRef] [PubMed]

61. Larrosa-Haro, A.; Flores-Fong, L.E. Fecal Excretion of Reducing Substances in Infants with Dyschezia. J. Pediatr. Gastroenterol. Nutr. 2013, 57, E82.

62. Codex Alimentarius Food Standards Commission. Standard for infant formula and formulas for special medical purposes intended for infants. Codex Standard number 72-1981, revision 2007. pp. 1-21. Available online: http://www.fao.org/fao-who-codexalimentarius/sh-proxy/en/?lnk=1\&url=https\%253A\%252F\% 252Fworkspace.fao.org\%252Fsites\%252Fcodex\%252FStandards\%252FCXS\%2B72-1981\%252FCXS_072e. pdf (accessed on 12 November 2019).

63. Hertzler, S.R.; Huynh, B.C.L.; Savaiano, D.A. How much lactose is low lactose? J. Am. Diet. Assoc. 1996, 96, 243-246. [CrossRef]

64. Deng, Y.; Misselwitz, B.; Dai, N.; Fox, M. Lactose intolerance in adults: Biological mechanism and dietary management. Nutrients 2015, 7, 8020-8035. [CrossRef] [PubMed]

65. Gasbarrini, A.; Corazza, G.R.; Gasbarrini, G.; Montalto, M.; Di Stefano, M.; Basilisco, G.; Parodi, A.; Satta, P.U.; Vernia, P.; Anania, C.; et al. Methodology and indications of H2-breath testing in gastrointestinal diseases: The Rome consensus conference. Aliment. Pharmacol. Ther. 2009, 29, 1-3. [PubMed]

66. Lomer, M.C.E. The aetiology, diagnosis, mechanisms and clinical evidence for food intolerance. Aliment. Pharmacol. Ther. 2015, 41, 262-275. [CrossRef] [PubMed]

67. Mattar, R.; Mazo, de Campos Mazo, D.F.; Carrilho, F.J. Lactose intolerance: Diagnosis, genetic, and clinical factors. Clin. Exp. Gastroenterol. 2012, 5, 113-121.

68. Lukito, W.; Malik, S.G.; Surono, I.S.; Wahlqvist, M.L. From "lactose intolerance" to "lactose nutrition". Asia Pac. J. Clin. Nutr. 2015, 24, S1-S8. [PubMed]

69. Rosado, J.L.; Gonzalez, C.; Valencia, M.E.; López, P.; Palma, M.; López, B.; Mejía, L.; Báez, M. Lactose maldigestion and milk intolerance: A study in rural and urban Mexico using physiological doses of milk. J. Nutr. 1994, 124, 1052-1059. [CrossRef] [PubMed]

70. EFSA Panel on Dietetic Products, Nutrition and Allergies (NDA). Scientific Opinion on lactose thresholds in lactose intolerance and galactosaemia. EFSA J. 2010, 8, 1777. [CrossRef]

71. Suchy, F.J.; Brannon, P.M.; Carpenter, T.O.; Fernandez, J.R.; Gilsanz, V.; Gould, J.B.; Hall, K.; Hui, S.L.; Lupton, J.; Mennella, J.; et al. NIH consensus development conference statement: Lactose intolerance and health. NIH Consens. State Sci. Statements 2010, 27, 1-27. [PubMed]

72. Matte, J.J.; Britten, M.; Girard, C.L. The importance of milk as a source of vitamin B12 for human nutrition. Anim. Front. 2014, 4, 32-37. [CrossRef]

73. Soeparto, P.; Stobo, E.A.; Walker-Smith, J.A. Role of chemical examination of the stool in diagnosis of sugar malabsorption in children. Arch. Dis. Child. 1972, 47, 56-61. [CrossRef] [PubMed]

74. Agostoni, C.; Turck, D. Is cow's milk harmful to a child's health? J. Pediatr. Gastroenterol. Nutr. 2011, 53, 594-600. [PubMed]

75. Guzmàn-Maldonado, H.; Paredes-Lòpez, O.; Biliaderis, C.G. Amylolytic enzymes and products derived from starch: A review. Crit. Rev. Food Sci. Nutr. 1995, 35, 373-403. [CrossRef] [PubMed]

76. Hofman, D.L.; van Buul, V.J.; Brouns, F.J.P.H. Nutrition, health, and regulatory aspects of digestible maltodextrins. Crit. Rev. Food Sci. Nutr. 2016, 56, 2091-2100. [CrossRef] [PubMed]

77. Augustin, L.S.A.; Kendall, C.W.C.; Jenkins, D.J.A.; Willett, W.C.; Astrup, A.; Barclay, A.W.; Björck, I.; Brand-Miller, J.C.; Brighenti, F.; Buyken, A.E.; et al. Glycemic index, glycemic load and glycemic response: An International Scientific Consensus Summit from the International Carbohydrate Quality Consortium (ICQC). Nutr. Metab. Cardiovasc. Dis. 2015, 25, 795-815. [CrossRef] [PubMed]

78. Slupsky, C.M.; He, X.; Hernell, O.; Andersson, Y.; Rudolph, C.; Lönnerdal, B.; West, C.E. Postprandial metabolic response of breast-fed infants and infants fed lactose-free vs regular infant formula: A randomized controlled trial. Sci. Rep. 2017, 7, 3640. [CrossRef] [PubMed]

79. Keim, N.L.; Levin, R.J.; Havel, P.J. Carbohydrates. In Modern Nutrition in Health and Disease; Jones \& Bartlett Learning: Burlington, MA, USA, 2014; pp. 36-57.

80. Adeva-Andany, M.M.; Perez-Felpete, N.; Fernandez-Fernandez, C.; Donapetry-Garcia, C.; Pazos-Garcia, C. Liver glucose metabolism in humans. Biosci. Rep. 2016, 36, e00416. [CrossRef] [PubMed] 
81. Young, B.E.; Tang, M.; Griese, K.; Krebs, N.F. Consumption of a corn-sugar based infant formula is associated with higher C-peptide secretion compared to lactose based formula among exclusively formula fed infants. FASEB J. 2016, 30, 1. supplement, 673.7.

82. Guilbaud, A.; Niquet-Leridon, C.; Boulanger, E.; Tessier, F. How can diet affect the accumulation of advanced glycation end-products in the human body? Foods 2016, 5, 84. [CrossRef] [PubMed]

83. Gupta, A.; Uribarri, J. Dietary advanced glycation end products and their potential role in cardiometabolic disease in children. Horm. Res. Paediatr. 2016, 85, 291-300. [CrossRef] [PubMed]

84. Mills, D.J.S.; Tuohy, K.M.; Booth, J.; Buck, M.; Crabbe, M.J.C.; Gibson, G.R.; Ames, J.M. Dietary glycated protein modulates the colonic microbiota towards a more detrimental composition in ulcerative colitis patients and non-ulcerative colitis subjects. J. Appl. Microbiol. 2008, 105, 706-714. [CrossRef] [PubMed]

85. Nickerson, K.P.; Chanin, R.; McDonald, C. Deregulation of intestinal anti-microbial defense by the dietary additive, maltodextrin. Gut Microbes 2015, 6, 78-83. [CrossRef] [PubMed]

86. Laudisi, F.; Di Fusco, D.; Dinallo, V.; Stolfi, C.; Di Grazia, A.; Marafini, I.; Colantoni, A.; Ortenzi, A.; Alteri, C.; Guerrieri, F; et al. The food additive maltodextrin promotes endoplasmic reticulum stress-driven mucus depletion and exacerbates intestinal inflammation. Cell. Mol. Gastroenterol. Hepatol. 2019, 7, 457-473. [CrossRef] [PubMed]

87. Dao, M.C.; Clément, K. Gut microbiota and obesity: Concepts relevant to clinical care. Eur. J. Intern. Med. 2018, 48, 18-24. [CrossRef] [PubMed]

88. Santos-Marcos, J.A.; Perez-Jimenez, F.; Camargo, A. The role of diet and intestinal microbiota in the development of metabolic syndrome. J. Nutr. Biochem. 2019, 70, 1-27. [CrossRef] [PubMed]

89. Beauchamp, G.K.; Mennella, J.A. Flavor perception in human infants: Development and functional significance. Proc. Dig. 2011, 83, 1-6. [CrossRef] [PubMed]

90. Forestell, C.A. Flavor perception and preference development in human infants. Ann. Nutr. Metab. 2017, 70, 17-25. [CrossRef] [PubMed]

91. Delaveau, P. Brief survey about feeding and obesity. Ann. Pharm. Fr. 2004, 62, 103-110. [CrossRef]

92. Blass, E.M.; Shide, D.J. Some comparisons among the calming and pain-relieving effects of sucrose, glucose, fructose and lactose in infant rats. Chem. Senses 1994, 19, 239-249. [CrossRef] [PubMed]

93. Blass, E.M.; Shah, A. Pain-reducing properties of sucrose in human newborns. Chem. Senses 1995, 20, 29-35. [CrossRef] [PubMed]

94. González de Cosío, T.; Escobar-Zaragoza, L.; González-Castell, L.D.; Rivera-Dommarco, J.Á. Infant feeding practices and deterioration of breastfeeding in Mexico. Salud Publica Mex. 2013, 55 (Suppl. 2), S170-S179.

95. Walker, R.W.; Goran, M.I. Laboratory determined sugar content and composition of commercial infant formulas, baby foods and common grocery items targeted to children. Nutrients 2015, 7, 5850-5867. [CrossRef] [PubMed]

96. Fidler Mis, N.; Braegger, C.; Bronsky, J.; Campoy, C.; Domellöf, M.; Embleton, N.D.; Hojsak, I.; Hulst, J.; Indrio, F.; Lapillonne, A.; et al. Sugar in infants, children and adolescents: A position paper of the ESPGHAN Committee on Nutrition. J. Pediatr. Gastroenterol. Nutr. 2017, 6, 681-696. [CrossRef] [PubMed]

97. Schönfeld, P.; Wojtczak, L. Short- and medium-chain fatty acids in energy metabolism: The cellular perspective. J. Lipid Res. 2016, 57, 943-954. [CrossRef] [PubMed]

98. Bouwman, L.M.S.; Fernandez-Calleja, J.M.S.; van der Stelt, I.; Oosting, A.; Keijer, J.; van Schothorst, E.M. Replacing part of glucose with galactose in the postweaning diet protects female but not male mice from high-fat diet-induced adiposity in later life. J. Nutr. 2019, 148, 1-9. [CrossRef] [PubMed]

99. Maldonado Galdeano, C.; Cazorla, S.I.; Lemme Dumit, J.M.; Vélez, E.; Perdigón, G. Beneficial effects of probiotic consumption on the immune system. Ann. Nutr. Metab. 2019, 74, 115-124. [CrossRef] [PubMed]

100. Mysorekar, I.U.; Cao, B. Microbiome in parturition and preterm birth. Semin. Reprod. Med. 2014, 32, 50-55. [PubMed]

101. Aagaard, K.; Ma, J.; Antony, K.M.; Ganu, R.; Petrosino, J.; Versalovic, J. The placenta harbors a unique microbiome. Sci. Transl. Med. 2014, 6, 237. [CrossRef] [PubMed]

102. Stinson, L.F.; Payne, M.S.; Keelan, J.A. Planting the seed: Origins, composition, and postnatal health significance of the fetal gastrointestinal microbiota. Crit. Rev. Microbiol. 2017, 43, 352-369. [CrossRef] [PubMed]

103. Hawrelak, J.A.; Myers, S.P. The causes of intestinal dysbiosis: A review. Altern. Med. Rev. 2004, 9, $180-197$. [PubMed] 
104. O'Callaghan, A.; van Sinderen, D. Bifidobacteria and their role as members of the human gut microbiota. Front. Microbiol. 2016, 7, 925. [CrossRef] [PubMed]

105. García-Mantrana, I.; Bertua, B.; Martínez-Costa, C.; Collado, M.C. Perinatal nutrition: How to take care of the gut microbiota? Clin. Nutr. Exp. 2016, 6, 3-16. [CrossRef]

106. Tanaka, M.; Nakayama, J. Development of the gut microbiota in infancy and its impact on health in later life. Allergol. Int. 2017, 66, 515-522. [CrossRef] [PubMed]

107. Kato, K.; Ishida, S.; Tanaka, M.; Mitsuyama, E.; Xiao, J.Z.; Odamaki, T. Association between functional lactase variants and a high abundance of Bifidobacterium in the gut of healthy Japanese people. PLoS ONE 2018, 13, e0206189. [CrossRef] [PubMed]

108. Szilagyi, A. Adaptation to lactose in lactase non persistent people: Effects on intolerance and the relationship between dairy food consumption and evalution of diseases. Nutrients 2015, 7, 6751-6779. [CrossRef] [PubMed]

109. Daly, K.; Darby, A.C.; Hall, N.; Nau, A.; Bravo, D.; Shirazi-Beechey, S.P. Dietary supplementation with lactose or artificial sweetener enhances swine gut Lactobacillus population abundance. Br. J. Nutr. 2014, 111, S30-S35. [CrossRef] [PubMed]

110. Francavilla, R.; Calasso, M.; Calace, L.; Siragusa, S.; Ndagijimana, M.; Vernocchi, P.; Brunetti, L.; Mancino, G.; Tedeschi, G.; Guerzoni, E.; et al. Effect of lactose on gut microbiota and metabolome of infants with cow's milk allergy. Pediatr. Allergy Immunol. 2012, 23, 420-427. [CrossRef] [PubMed]

111. Li, X.; Yin, J.; Zhu, Y.; Wang, X.; Hu, X.; Bao, W.; Huang, Y.; Chen, L.; Chen, S.; Yang, W.; et al. Effects of whole milk supplementation on gut microbiota and cardiometabolic biomarkers in subjects with and without lactose malabsorption. Nutrients 2018, 10, 1403. [CrossRef] [PubMed]

112. Aakko, J.; Kumar, H.; Rautava, S.; Wise, A.; Autran, C.; Bode, L.; Isolauri, E.; Salminen, S. Human milk oligosaccharide categories define the microbiota composition in human colostrum. Benef. Microbes 2017, 8 , 563-567. [CrossRef] [PubMed]

113. Boehm, G. Supplementation of a bovine milk formula with an oligosaccharide mixture increases counts of faecal bifidobacteria in preterm infants. Arch. Dis. Child. Fetal Neonatal Ed. 2002, 86, 178F-181F. [CrossRef] [PubMed]

114. Ben, X.M.; Zhou, X.Y.; Zhao, W.H.; Yu, W.L.; Pan, W.; Zhang, W.L.; Wu, S.M.; Van Beusekom, C.M.; Schaafsma, A. Supplementation of milk formula with galacto-oligosaccharides improves intestinal micro-flora and fermentation interm infants. Chin. Med. J. 2004, 117, 927-931. [PubMed]

115. Savaiano, D.A.; Ritter, A.J.; Klaenhammer, T.R.; James, G.M.; Longcore, A.T.; Chandler, J.R.; Walker, W.A.; Foyt, H.L. Improving lactose digestion and symptoms of lactose intolerance with a novel galacto-oligosaccharide (RP-G28): A randomized, double-blind clinical trial. Nutr. J. 2013, 12, 160. [CrossRef] [PubMed]

116. Krumbeck, J.A.; Rasmussen, H.E.; Hutkins, R.W.; Clarke, J.; Shawron, K.; Keshavarzian, A.; Walter, J. Probiotic Bifidobacterium strains and galactooligosaccharides improve intestinal barrier function in obese adults but show no synergism when used together as synbiotics. Microbiome 2018, 6, 121. [CrossRef] [PubMed]

117. Azcarate-Peril, M.A.; Ritter, A.J.; Savaiano, D.; Monteagudo-Mera, A.; Anderson, C.; Magness, S.T.; Klaenhammer, T.R. Impact of short-chain galactooligosaccharides on the gut microbiome of lactose-intolerant individuals. Proc. Natl. Acad. Sci. USA 2017, 114, E367-E375. [CrossRef] [PubMed]

118. West, C.E.; Renz, H.; Jenmalm, M.C.; Kozyrskyj, A.L.; Allen, K.J.; Vuillermin, P.; Prescott, S.L. The gut microbiota and inflammatory noncommunicable diseases: Associations and potentials for gut microbiota therapies. J. Allergy Clin. Immunol. 2015, 135, 3-13. [CrossRef] [PubMed]

119. López-Velázquez, G.; Parra-Ortiz, M.; De la Mora-De la Mora, I.; García-Torres, I.; Enríquez-Flores, S.; Alcántara-Ortigoza, M.A.; González-del Angel, A.; Velázquez-Aragón, J.; Ortiz-Hernández, R.; Cruz-Rubio, J.M.; et al. Effects of fructans from Mexican agave in newborns fed with infant formula: A randomized controlled trial. Nutrients 2015, 7, 8939-8951. [CrossRef] [PubMed]

120. Binder, H.J. Role of colonic short-chain fatty acid transport in diarrhea. Annu. Rev. Physiol. 2010, 72, $297-313$. [CrossRef] [PubMed]

121. Hertzler, S.R.; Savaiano, D.A. Colonic adaptation to daily lactose feeding in lactose maldigesters reduces lactose intolerance. Am. J. Clin. Nutr. 1996, 64, 232-236. [CrossRef] [PubMed]

122. Leturque, A.; Brot-Laroche, E.; Le Gall, M.; Stolarczyk, E.; Tobin, V. The role of GLUT2 in dietary sugar handling. J. Physiol. Biochem. 2005, 61, 529-537. [CrossRef] [PubMed] 
123. Moore, M.C.; Coate, K.C.; Winnick, J.J.; An, Z.; Cherrington, A.D. Regulation of hepatic glucose uptake and storage in vivo. Adv. Nutr. 2012, 3, 286-294. [CrossRef] [PubMed]

124. Kwak, H.S.; Lee, W.J.; Lee, M.R. Revisiting lactose as an enhancer of calcium absorption. Int. Dairy J. 2012, 22, 147-151. [CrossRef]

125. Saulnier, D.M.; Spinler, J.K.; Gibson, G.R.; Versalovic, J. Mechanisms of probiosis and prebiosis: Considerations for enhanced functional foods. Curr. Opin. Biotechnol. 2009, 20, 135-141. [CrossRef] [PubMed]

126. Williams, C.A.; Phillips, T.; Macdonald, I. The influence of glucose on serum galactose levels in man. Metabolism 1983, 32, 250-256. [CrossRef]

127. van Weeren, P.C.; De Bruyn, K.M.T.; De Vries-Smits, A.M.M.; van Lint, J.; Burgering, B.M.T. Essential role for protein kinase $B(\mathrm{PKB})$ in insulin-induced glycogen synthase kinase 3 inactivation. Characterization of dominant-negative mutant of PKB. J. Biol. Chem. 1998, 273, 13150-13156. [CrossRef] [PubMed]

128. Nuttall, F.Q.; Gannon, M.C. Dietary management of type 2 diabetes: A personal odyssey. J. Am. Coll. Nutr. 2007, 26, 83-94. [CrossRef] [PubMed]

129. Urashima, T.; Fukuda, K.; Messer, M. Evolution of milk oligosaccharides and lactose: A hypothesis. Animal 2012, 6, 369-374. [CrossRef] [PubMed]

130. Shwe, T.; Pratchayasakul, W.; Chattipakorn, N.; Chattipakorn, S.C. Role of D-galactose-induced brain aging and its potential used for therapeutic interventions. Exp. Gerontol. 2018, 101, 13-36. [CrossRef] [PubMed]

131. Soares, A.F.; Carvalho, R.A.; Veiga, F.J.; Jones, J.F. Effects of galactose on direct and indirect pathways estimates of hepatic glycogen synthesis. Metab. Eng. 2010, 12, 552-560. [CrossRef] [PubMed]

132. Elsas, L.J.; Acosta, P.B. Inherited metabolic disease: Amino acids, organic acids, and galactose. In Modern Nutrition in Health and Disease, 11th ed.; Ross., A.C., Caballero, B., Cousins, R.J., Tucker, K.L., Ziegler, T.R., Eds.; Lippincott Williams \& Wilkins: Philadelphia, PA, USA, 2014; pp. 906-969.

133. Tormo, R.; Martin, B.; Rivero, G.C.; Dominguez, V.; Segurola, H.; Cardenas, G. Lactose intake and brain functions. In Proceedings of the ESPGHAN Congres 2019, Glasgow, UK, 5-8 June 2019; p. N-P-088.

134. Guo, J.; Givens, D.; Astrup, A.; Bakker, S.J.L.; Goossens, G.H.; Kratz, M.; Marette, A.; Pijl, H.; Soedamah-Muthu, S.S. The impact of dairy products in the development of type 2 diabetes: Where does the evidence stand in 2019? Adv. Nutr. 2019, 1-10. [CrossRef] [PubMed]

135. Chia, J.S.J.; McRae, J.L.; Kukuljan, S.; Woodford, K.; Elliott, R.B.; Swinburn, B.; Dwyer, K.M. A1 beta-casein milk protein and other environmental pre-disposing factors for type 1 diabetes. Nutr. Diabetes 2017, 15, e274. [CrossRef] [PubMed]

136. Hilger, J.; Friedel, A.; Herr, R.; Rausch, T.; Roos, F.; Wahl, D.A.; Pierroz, D.D.; Weber, P.; Hoffmann, K.A. Systematic review of vitamin D status in populations worldwide. Br. J. Nutr. 2014, 14, 23-45. [CrossRef] [PubMed]

137. Mohr, S.B.; Garland, C.F.; Gorham, E.D.; Garland, F.C. The association between ultraviolet B irradiance, vitamin D status and incidence rates of type 1 diabetes in 51 regions worldwide. Diabetologia 2008, 51, 1391-1398. [CrossRef] [PubMed]

138. Writing Group for the TRIGR Study Group; Knip, M.; Åkerblom, H.K.; Al Taji, E.; Becker, D.; Bruining, J.; Castano, L.; Danne, T.; de Beaufort, C.; Dosch, H.M.; et al. Effect of hydrolyzed infant formula vs conventional formula on risk of type 1 diabetes. The TRIGR randomized clinical trial. JAMA 2018, 319, 38-48. [PubMed] 